lar coppice crops of eucalypt timber. This suggests that, in appropriate locations which have convenient access to a source of town refuse and, ideally, also irrigation water, reclaimed spoil-soils can be successfully used for the simultaneous cultivation of agricultural crops and eucalypts. Under this relatively intensive intercropping system, the eucalypts do not appear to have any of the adverse effects on soil nutrient status that have been reported for the noncultivated eucalypt plantations elsewhere on the Jos Plateau.

\section{Acknowledgement}

The European Community, under the European Development Fund, financed the Jos Plateau Environmental Resources Development Programme of which this Project was a part.

\section{REFERENCES}

AdEPETU, A.A. (1985). Farmers and Their Farms on Four Fadamas on the Jos Plateau. Interim Report No. 2, Jos Plateau Environmental Resources Development Programme, University of Durham, Durham, England, UK: 24 pp., illustr.

ALEXANDER, M.J. (1985). A History of Mine Land Reclamation on the Jos Plateau. Interim Report No. 4, Jos Plateau Environ- mental Resources Development Programme, University of Durham, Durham, England, UK: 24 pp., illustr.

AleXANDER, M. (1986). Soil Characteristics and the Factors Influencing Their Development on Mine Spoil of the Jos Plateau. Interim Report No. 11, Jos Plateau Environmental Resources Development Programme, University of Durham, Durham, England, UK: 167 pp., illustr.

BUCKLEY, G.P. (1988). Soil factors influencing yields of Eucalyptus camaldulensis on former tin-mining land in the Jos Plateau Region, Nigeria. Forest Ecology and Management, 23, pp. $1-17$.

Joyce, C. (1988). The tree that caused a riot. New Scientist, $117(1600)$, pp. 54-9.

Kardell, L., Steen, F. \& Fabiao, A. (1986). Eucalyptus in Portugal-a threat or a promise? Ambio, 15, pp. 6-13.

SECOND Citizens RePORT (1985). The State of India's Environment 1984-85. Centre for Science and Education, New Delhi, India: 393 pp., illustr.

WIMBUSH, S.H. (1963). Afforestation of restored tin-mining land in Nigeria. Commonw. For. Rev., 42, pp. 255-62.

Michael J. AleXander Department of Geography University of Durham

Durham DHI $3 L E$

England, $U K$.

\title{
Shadow-pricing Environmental Goods and Services, Using the Enmergy Method
}

The enmergy method aims at aggregating energy and building an energy-quality hierarchy for analysing ecosystems and environmental-economic bridged systems. A special case exists in shadow-pricing environmental goods and services which appear as energy externalities to economic subsystems. In this note, we contribute by clarifying the enmergy accounting of these external, non-priced contributions to economic processes.

\section{Prerequisites}

The analytical idea behind the enmergy method (namely Howard T. Odum's conceptualization of the embodiedenergy theory-see Odum, 1983, 1984, 1986; Pillet, 1987; Scienceman, 1987) is that, at each step of an energy-chain, much of the energy is used in the transformation, but only a small amount is converted into a higher quality of energy that is, into a more concentrated form which is capable of catalytic action when fed back. Then, the ratio of one form of energy that is required to generate another form of energy by a transformation, is a measure of efficiency according to the First and Second Laws of Thermodynamics, under the Maximum Power principle (or, maximum energy-flux per unit of time according to the Lotka-Odum autocatalytic characterization of living as well as Manmade non-living processes). In other words, this ratio is a measure of energy quality in real systems when the latter tend to operate at that efficiency which produces a Maximum Power output. This ratio of one (source) form of energy required to develop another (high-quality) form of energy by a transformation has been called transformity (symbol: $\mathrm{Tr}$ ). The term 'transformity' thus names a ratio describing the quality of a form of energy and its measurable ability to amplify as feedback relative to the sourceenergy consumed in its formation, and under the Maximum Power principle (Scienceman, 1987).

Embodied energy (now, enmergy; symbol: C) is defined by Howard $\mathrm{T}$. Odum as a way to measure the cumulative action of energies in chains or webs (Odum, 1983). It is the source-energy required to produce a form of energy. As a result, if different-form energies are to be compared with respect to the energies required in their formation (or their effect), they may be converted into the same sourceenmergy (that is, into equivalents of the same form) by multiplying their actual energy content by their (source) transformity.

If the joule is the current unit for actual transformation work, it is not qualified for dimensioning enmergy, the unit of which is the source equivalent joule. This new unit has been called enmjoule (symbol: enmJ).

Thus, the analysing of ecological-economic subsystems requires that every energy-form participating in the product be first evaluated in actual joules, and then converted into enmergy (enmJ) by means of the appropriate (in situ) transformity.

Finally, a special ratio is used in ecological-economic systems which characterizes the period-to-period relationships between the enmergy used by a country and its GNP. This enmergy/\$ ratio has been called monergy. It is used for calculating macro-prices as well as for calibrating human services by means of enmergy units. It is defined by the global enmergy used within the country (in enmJ) divided by the GNP of the country (in \$); it is thus expressed as an enmJ $/ \$$ ratio.

\section{Accounting for Unpaid Prices}

Macro-prices, or shadow-prices (symbol: p) for environmental goods and services (symbol: I; otherwise called energy externalities - see Pillet, 1986, 1987) can be taken into account, using the concepts of the enmergy method given above.

Based on Odum (1983; cf. also Lavine \& Butler, 1982), our general hypothesis is that the shadow-price of environmental goods and services, per surface and period of time, is in proportion to the GNP in value in this period, as is the global enmergy of these goods and services per surface and period of time in proportion to the global enmergy used by the country within the same period. 
This gives us:

shadow-prices of environmental goods (or $\mathrm{p}_{\mathrm{I}}$ ) per ha per year

GNP (Gross National Product) in value of the country $=$

Enmergy of environmental goods (or $\mathrm{C}_{1}^{*}$ ) per ha per year

Total enmergy (or $\mathrm{C}^{*}$ ) used by the country

In symbols, we obtain for $\mathrm{P}_{\mathrm{I}}$ :

$\mathrm{P}_{\mathrm{I}} / \mathrm{ha} / \mathrm{yr}=\left(\mathrm{C}^{*}{ }_{\mathrm{I}} / \mathrm{ha} / \mathrm{yr}\right) *(\mathrm{GNP}) /\left(\mathrm{C}^{*}\right.$ used by the country).

Yet, the GNP/C* ratio is the reciprocal of the enmergy/\$ ratio (or, monergy), giving us, in symbols:

$\mathrm{P}_{\mathrm{I}} / \mathrm{ha} / \mathrm{yr}=\left(\mathrm{C}_{\mathrm{I}}^{*} / \mathrm{ha} / \mathrm{yr}\right.$ in enmJ $) /($ monergy, or enmJ $/ \$$ ratio)

that is, the shadow-price of environmental goods per ha per year is obtained by dividing their enmergy by the monergy of the country. Note that this can be correct up to a $10 \%$ contribution from the output $\mathrm{Y}$ (see Fig. 1) to the national economy. If the output is more than $10 \%$ of the GNP, we use a corrected monergy.

This model of enmergy calculation may be used to calibrate human labour within environmental-economic subsystems with the necessary modifications. In this respect, the enmergy of human labour is obtained by multiplying wages by the monergy of the country (or of a subsystem).

In conclusion, these calculations should apply to any enmergy analysis of ecologic-economic systems, including the shadow pricing of energy externalities within economic subsystems. Such macro-prices should be considered as indicators of ecosystems' work in economic calculations, thus contributing to the integration of ecological considerations into economic analysis.

\section{REFERENCES}

LAVINE, J.J. \& BUtLER, T.J. (1982). Use of Embodied Energy Values to Price Environmental Factors: Examining the Embodied Energy/Dollar Relationship. Final report on NSF Award PRA-8003845. Center for Environmental Research, Department of Environmental Engineering, Cornell University, Ithaca, NY, USA : 40 pp. + Appendices A-I, illustr. [The results of this specific study's regression analysis have shown that the sunlight measure of embodied energy value might explain from 92 to $99 \%$ of the variation in economic value cross-sectionally ( 87 sectors), and from 95 to $99 \%$ temporally (1929-76 for the U.S. economy).] Cf. also C.J.R. CLEVELAND

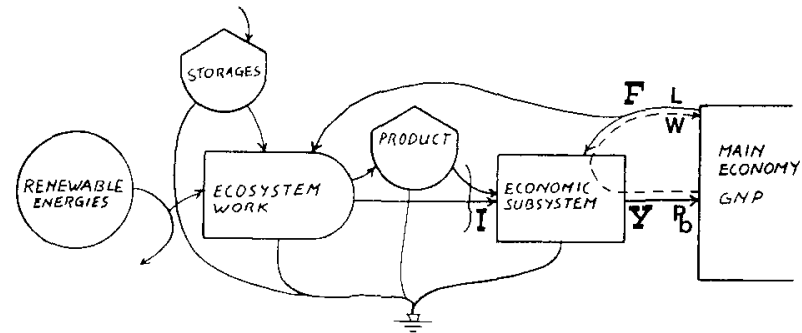

FIG. 1. Shadow-pricing environmental goods and services using the concept of enmergy of the environment. The processing of an environmental value (I) by an economic subsystem leads to the enmergy calibration of this value as an energy externality. In turn, this externality may be priced at the proportion that the environmental work is of the nation's total work, both being given in energy units of the same quality, or enmjoules.

et al. (1984), Energy and the U.S. economy: a biophysical perspective (Science, 204, pp. 890-7).

ODUM, H.T. (1983). Systems Ecology-an Introduction. John Wiley \& Sons, New York-Chichester-Brisbane-TorontoSingapore: $x v+644$ pp., illustr.

ODum, H.T. (1984). Summary: Cypress swamps and their regional role. Pp. 416-43 in Cypress Swamps (Eds K.C. EwEL \& H.T. ODUm). University of Florida Press, Gainesville, Florida, USA: xviii +472 pp., illustr.

Odum, H.T. (1986). Enmergy in ecosystems. Pp. 337-69 in Ecosystem Theory and Application (Ed. N. POLUNIN). John Wiley \& Sons, Chichester-New York-Brisbane-Toronto-Singapore: $x v+445$ pp., illustr. [On this occasion, Nicholas Polunin suggested to use the terms enmergy and enmjoule instead of 'emergy' and 'emjoule' to avoid confusion.]

Pillet, G. (1986). From external effects to energy externality: New proposals in environmental economics. Hitotsubashi Journal of Economics, 27(1), pp. 77-97.

Pillet, G. (1987). Case-study of the role of environment as an energy externality in Geneva vineyard cultivation and wine production. Environmental Conservation, 14(1), pp. 53-8, 19 figs.

SCIENCEMAN, D.M. (1987). Energy and emergy. Pp. 257-76 in Environmental Economics - the Analysis of a Major Interface (Eds G. Pillet \& T. Murota). R. Leimgruber, 9 rue Jentzer. Geneva, Switzerland: $x+310$ pp., illustr.

\section{Gonzague Pillet \\ \& \\ ANDREA BARANZINI \\ Centre for Human Ecology \& Environmental Sciences University of Geneva \\ Box 266 \\ 1227 Carouge \\ Geneva, Switzerland.}

\section{The United States' Nuclear Defense Industry}

\section{Introduction}

Soothsayers and prophets of doom have never had more ammunition in their dismal arsenals than when they report the bleak prospects that would attend a nuclear holocaust. The ensuing 'nuclear winter' would enshroud the Earth in smoke and dust and would moreover be accompanied by a substantial reduction in planetary temperature. A dark, cold, toxin-laden world would be home only to the hardiest individuals that proved able to survive massive doses of ionizing radiation (Lown, 1986; Westing, 1987).

The likelihood of a nuclear war may be greater than many people suspect; but that is only one of several possible apocalyptic scenarios (Lown, 1986; American Public
Health Association, 1986). Americans have always maintained a proclivity to think in grand terms, and in the case of disasters they often envision a cataclysmic end. Perhaps T. S. Elliot (1952 p. 287) was a more astute prognosticator of Mankind's eventual demise when he predicted:

'This is the way the world ends

This is the way the world ends

This is the way the world ends

Not with a bang but a whimper.'

\section{The Nuclear Defense Industry}

An underpublicized threat to public health and safety involves what until recently has been a well-kept secret. 